\title{
Impact of Swiss Needle-Cast on Growth of Douglas-Fir
}

\author{
M. O. Kimberley, I. A. Hood, and R. L. Knowles
}

Scion (New Zealand Forest Research Institute Ltd.), Private Bag 3020, Rotorua, New Zealand.

Accepted for publication 25 September 2010.

\begin{abstract}
Kimberley, M. O., Hood, I. A., and Knowles, R. L. 2011. Impact of Swiss needle-cast on growth of Douglas-fir. Phytopathology 101:583-593.

Phaeocryptopus gaeumannii, the cause of Swiss needle-cast, is widely distributed in plantations of Douglas-fir in many parts of the world. Nevertheless, information remains limited on its precise effect on stand growth, particularly in relation to regional climate, and on its consequent economic cost. In New Zealand, the spread of $P$. gaeumannii over a period of $\approx 30$ years following its discovery in 1959 was closely monitored, and the timing of its arrival in different forests is known. This information was coupled with data from permanent sample plots in order to quantify the associated historical growth increment loss. Analyses

appearance of $P$. gaeumannii to a point when it stabilized at a lower increment level 14 to 20 years later. The cumulative mean reduction was $25 \%$ for mean top height, $27 \%$ for basal area, and $32 \%$ for stem volume. Volume growth rate decline was greater in the North Island (35\%) than the South Island (23\%) of New Zealand. These reductions in volume growth are estimated to equate to a loss in net present value of \$NZ2,620 $\mathrm{ha}^{-1}$ and $\$ \mathrm{NZ1}, 470 \mathrm{ha}^{-1}$ for the North and South Islands, respectively, using a discount rate of $6 \%$. Mortality did not increase as a result of infection by $P$. gaeumannii. The disease had less effect on cooler sites, especially those with low spring minimum temperatures $(P<0.001)$. Negligible growth decline occurred on sites with daily minimum October temperatures averaging $<3.2^{\circ} \mathrm{C}$.
\end{abstract} revealed a steady decline in growth rate over the period from the first
The ascomycete fungus Phaeocryptopus gaeumannii (T. Rhode) Petr. occurs naturally as a microparasite within needles of Douglas-fir (Pseudotsuga menziesii (Mirb.) Franco). In its native distribution range in western North America, it infects green foliage on healthy trees but, in most of the region, has negligible impact on its host $(2,14,25)$. Because of its generally innocuous and inconspicuous behavior, Phaeocryptopus gaeumannii remained unknown until 1925, when it was discovered associated with chlorotic and defoliating Douglas-fir planted in Switzerland (8). Swiss needle-cast has since spread to many parts of the world where Douglas-fir is grown, including much of Europe, central and eastern North America, Chile, and Australasia (3,9,23,34, $35,38,42,43,48,50)$. Since 1980 , the disease has become significant within the natural host range in western Oregon and Washington, initially in Christmas tree stands (39) and more recently in forest plantations, resulting in an intensive program of comprehensive research $(6,11,52,57,60)$.

P. gaeumannii was first found in New Zealand in 1959 on Douglas-fir growing near Taupo in the central North Island (9). The distribution of the fungus was carefully monitored as it subsequently spread and established in plantations throughout the country. Consequently, the year that infection appeared in various forests is known with reasonable precision $(9,15,18)$. P. gaeumannii took $\approx 10$ years to spread throughout North Island forests. It was first observed in the northern South Island in 1969, and took a further 20 years to spread to all significant South Island forests.

The role that $P$. gaeumannii plays in the disease, whether causative or merely as a secondary opportunistic associate, has been the subject of debate. Trees with infected foliage often appear discolored and partially defoliated (58) but, because symptoms are frequently both unspectacular and uneven, opinions

Corresponding author: M. O. Kimberley;

E-mail address: mark.kimberley @ scionresearch.com

doi:10.1094/PHYTO-05-10-0129

(c) 2011 The American Phytopathological Society have varied as to its real effect on stand health and growth $(3,4,12,41,43,46,47,56,61,63)$. In New Zealand, too, the lowprofile, protracted response by the infected host led to doubts about the true impact of $P$. gaeumannii (20). Nonetheless, observations have subsequently demonstrated that less older-age-class foliage is retained on heavily infected trees than on those still largely free of infection. A monitoring study over several years in a stand in Hanmer Forest in north Canterbury in the northeastern South Island clearly showed a gradual decrease in needle retention as infection concurrently invaded and grew to high levels $(16,18)$. Contemporary, heavily infected, younger-age-class Douglas-fir stands in the central North Island today appear a pale, mottled, yellow-green color for much of the year, including a significant part of the growing season, instead of the even, deeper shade of green characteristic of healthy plantations with low levels of infection. Inoculation studies with seedlings have established that $P$. gaeumannii plays a direct role in causing the premature shedding of needles and in reducing rates of photosynthesis $(13,30,55)$. It has been demonstrated that these effects result from a reduction in gaseous exchange due to plugging of the needle stomata by the developing fungal pseudothecia $(31,32)$

Although Swiss needle-cast has been known in Douglas-fir plantations for $>80$ years, there have been few comprehensive attempts to quantify the impact of $P$. gaeumannii on tree growth. It has not been straightforward to determine the effect of a slowly developing, cryptic disease, the precise cause of which was often still in debate (19). Reduction in growth was reported in some stands following infestation by $P$. gaeumannii in Denmark (58), and stem analyses conducted in southern Germany $(37,62)$, Austria (45), Denmark (26), the eastern United States (7), and southeastern Australia (36) all revealed reduced growth in selected diseased trees. Merkle (37), for instance, detected a significant growth reduction between 1935 and 1941, shortly after the advent of the fungus, and suggested that a decrease in growth increment of 50 to $70 \%$ could be expected in stands infected by $P$. gaeumannii. Growth decline was also reported in a number of diseased plantations in the United States, initially in Michigan (7) 
and later in Oregon $(1,21,28,29)$. In a detailed analysis of plots in 70 10- to 30-year-old plantations, Maguire et al. (28) concluded that the most heavily affected plantations in northwestern Oregon were showing basal area (BA) growth $35 \%$ less than that of healthy stands during the mid-1990s. In all of the above studies, the impacts of the disease have been analyzed by observing natural outbreaks. Assessing its effect by controlling the disease has seldom been attempted, although positive growth responses have been observed in trees treated with fungicide $(19,21)$.

In New Zealand, although it was at first assumed that infection would not affect Douglas-fir productivity (9), growth rates lower than predicted for parts of the North Island were soon causing concern. In Kaingaroa Forest, BA increments measured between 1964 and 1969 had fallen to one-third of the expected levels in older-age-class, first-rotation stands after $P$. gaeumannii was first recorded in this forest in 1960 (20). Younger infected stands in the same forest were subsequently found to be achieving only 60 to $74 \%$ of the BA increment attained by comparable stands prior to the introduction of the fungus (B. Manley, unpublished data). However, a comprehensive analysis of the impact of the disease on New Zealand forests has not yet been performed.

In addition, growth reduction in diseased stands may be influenced by regional climate, principally relating to moisture availability and air temperature. It was noticed in Europe that the distribution of Swiss needle-cast coincided with areas of higher rainfall $(5,37,55)$. In a survey of Douglas-fir stands in southern British Columbia, Hood (14) demonstrated that infection (measured by the percentage of needles with pseudothecia) was highly correlated with late spring rainfall, being slight or absent when May to July rainfall totaled $<110 \mathrm{~mm}$. Rosso and Hansen (49) analyzed data from a survey of 220 plantations in western Oregon and found a Swiss needle-cast severity rating (based on needle retention, height growth rate, and foliage color) to be related to various climatic and topographic variables. Manter et al. (33) used an estimate of the proportion of stomata occluded by pseudothecia to measure disease severity at nine forest sites in western Oregon and found a strong increase in needle infection with increasing winter temperature and, to a lesser extent, spring leaf wetness. In a survey of 16 New Zealand Douglas-fir stands covering a wide range of sites, Stone et al. (53) demonstrated a good association between the same infection variable and temperature, especially winter minimum temperature $\left(R^{2}=0.75\right)$. They found little evidence of the positive association between spring precipitation and disease severity noted in British Columbia by Hood (14) but attributed this to the fact that spring rainfall is typically abundant in New Zealand. The influence of climate on growth reduction, as opposed to infection, was also investigated in coastal Oregon. Tree-ring analysis was used to compare growth rates of older Douglas-fir with western hemlock (Tsuga heterophylla (Raf.) Sarg.) over time (1). Douglas-fir growth was found to be most reduced at sites with warmer spring and summer temperatures.

The existence in New Zealand of detailed records documenting the initial year of detection of the disease in each forest, along with an extensive set of growth data from permanent sample plots (PSPs) within these forests, provides a unique opportunity to study the historic impact on Douglas-fir growth caused by the arrival of the disease. The objective of this study was to utilize these data to test whether a change in growth rate could be detected as, or soon after, P. gaeumannii became established and, if so, to quantify this effect and estimate the consequent economic impact of the disease on the industry. A secondary objective was to test whether climatic factors had any modifying effect on the growth loss caused by the arrival of the disease in New Zealand. It was hoped that the results of these analyses would not only be of interest to New Zealand Douglas-fir growers but also contribute to a better understanding of the disease generally.

\section{MATERIALS AND METHODS}

Materials. Historical records of growth rates of Douglas-fir in New Zealand are available from an extensive database of PSP measurements maintained by Scion Research (44). The database contains measurements from $>1,500$ PSPs in Douglas-fir plantations, including PSPs in experimental field trials and growthmonitoring plots. Of most interest for this study were PSPs established sometime prior to the detection of P. gaeumannii and which continued to be monitored over the period following detection. An ideal PSP would have had measurements made prior to detection and for a reasonable period following detection. However, additional information which could be useful in establishing growth rates before the disease established might be obtained from plots which ceased to be measured shortly before the disease arrived. Similarly, useful information on the effect of the disease might be obtained from plots established a few years following detection.

Therefore, the available plots in each forest were screened to include all those that were at least 10 years old at the time the disease was detected in that forest, and with at least one measurement within 10 years of the detection date. There were 312 plots that satisfied all of the above criteria after excluding 3 extremely low productivity plots. Restrictions were also applied to individual measurements. Those made $>10$ years prior to detection or $>30$ years after detection were considered unlikely to provide useful information on the effect of the disease and were therefore excluded from the analysis. Because only stands aged $>10$ years at the time of detection were included, measurements made at very young ages were invariably made prior to detection while those in very old stands were mostly post infection. Therefore, to ensure a similar range of ages for pre- and post-detection measurements, only those made between ages 15 and 60 years were included in the analysis.

The response variables used in the analysis were measured increments of height, BA, and stem volume. All increments formed by pairs of consecutive measurements in each PSP were included in the analysis except for those made over periods of $<0.8$ years or $>5$ years. Several increments judged to be abnormal outliers were excluded from the analysis, mostly due to doubts concerning height measurements or to changes in plot boundaries between consecutive measurements. Because thinning events might be expected to have an immediate impact on growth rate, any increments starting within 5 years of a significant thinning

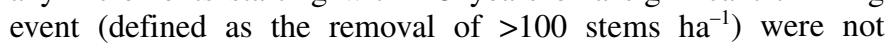
included in the analysis. In all, $\approx 300$ predetection and $\approx 1,200$ post-detection increments in 312 PSPs satisfied all of the above criteria. Numbers by forests of PSPs and measured increments used in the analysis are shown in Table 1.

First detections of $P$. gaeumannii in or near selected forests for which PSP data were available are shown in Table 1. These records were based on the laboratory confirmation of samples forwarded by trained field officers who routinely inspected forest plantations in their region at least once per year $(15,18)$.

Climatic variables were extracted for each PSP from biophysical GIS surfaces developed for New Zealand (24). The variables obtained were mean temperature, mean minimum temperature, and rainfall, with both annual and monthly means being extracted for all variables. Variables were obtained for locations to within $100 \mathrm{~m}$ when precise locations of PSPs were known but, for some PSPs where precise locations were not known, extractions were made at the central location of the forest.

Methods. In each PSP assessment, all stems within the bounded plot (typically 0.04 ha in area) were counted to provide an estimate of stocking (stems per hectare). All stems were measured for diameter at 1.4-m breast height (DBH) and a sample of stems was measured for height. From the DBH measurements, BA (square meters per hectare) was calculated. The measure of 
predominant height generally used in New Zealand, mean top height (MTH), defined as the mean height of the 100 largestdiameter stems per hectare (10), was obtained for each measurement from a height/DBH curve derived from the trees measured for height. Stem volume was estimated using an individual tree volume function applied to the $\mathrm{DBH}$ and height of each stem, with the latter estimated from the height/DBH curve when not measured. In this study, appropriate regional volume functions were used (T136 for North Island stands, T273 for the northern South Island, T275 for central South Island, and T274 for southern South Island). To check whether the choice of volume function might affect the analysis of volume growth decline, the analysis was also repeated using a single function (T136) for all measurements; however, because this produced very similar results, only the analysis using regional volume functions is reported.

The following variables were analyzed.

$$
\text { Hinc }\left(\mathrm{m} \mathrm{year}^{-1}\right)=\left(H_{2}-H_{1}\right) /\left(T_{2}-T_{1}\right)
$$

where $H_{1}$ and $H_{2}$ are MTH (meters) at the beginning and end of the increment, and $T_{1}$ and $T_{2}$ are age (years) at the beginning and end of the increment.

$$
\text { BAinc }\left(\mathrm{m}^{2} \text { ha }^{-1} \text { year }^{-1}\right)=\left(B A_{2}+B A_{\text {dead }}+B A_{\text {thin }}-B A_{1}\right) /\left(T_{2}-T_{1}\right)
$$

where $B A_{1}$ and $B A_{2}$ are $\mathrm{BA}$ (square meters per hectare) of live stems at the beginning and end of the increment, $B A_{\text {dead }}$ is the $\mathrm{BA}$ of any stems that died or were wind thrown during the increment period, and $B A_{\text {thin }}$ is the BA of any stems thinned during the increment period.

$$
\operatorname{Volinc}\left(\mathrm{m}^{3} \mathrm{ha}^{-1} \text { year }^{-1}\right)=\left(\operatorname{Vol}_{2}+\operatorname{Vol}_{\text {dead }}+\operatorname{Vol}_{\text {thin }}-\operatorname{Vol}_{1}\right) /\left(T_{2}-T_{1}\right)
$$

where $\mathrm{Vol}_{1}$ and $\mathrm{Vol}_{2}$ are stem volume (cubic meters per hectare) of live stems at the beginning and end of the increment, $V o l_{\text {dead }}$ is the stem volume of any stems that died or were wind thrown during the increment period, and Vol $_{\text {thin }}$ is the stem volume of any stems thinned during the increment period.

BAinc and Volinc are gross measures representing the growth rates of living trees and do not include any effect of mortality. Therefore, the following measure of mortality was also analyzed:

$$
\operatorname{Volmort}\left(\mathrm{m}^{3} \mathrm{ha}^{-1} \text { year }^{-1}\right)=\operatorname{Vol}_{\text {dead }} /\left(T_{2}-T_{1}\right)
$$

Because tree height is more difficult to measure accurately than diameter, and because MTH is derived from a fitted curve, MTH increments, especially over the short intervals of 1 to 4 years used in this study, tend to be more prone to error and show a greater number of outliers than BA increments. Therefore, to improve MTH values, a degree of smoothing was achieved by fitting a spline function to the MTH/age measurements in each PSP using the SAS (version 9.1) TPSPLINE procedure. The smoothed MTH values were then used to calculate MTH increments and were also used to correct the stem volume increments. This procedure improved the precision of estimates in the subsequent analysis but did not alter overall conclusions.

The purpose of the analysis was to quantify the effect of the advent of $P$. gaeumannii on Douglas-fir measured growth increments. This was achieved using linear mixed models fitted using the SAS (version 9.1) MIXED procedure. Because it was not considered desirable to assume any particular function to represent time in relation to the initial detection of $P$. gaeumannii, this was included in the model as a class factor with different levels for each integer value of the number of years from the

\begin{tabular}{|c|c|c|c|c|c|c|}
\hline \multirow[b]{2}{*}{ Forest plantation } & \multirow[b]{2}{*}{ Latitude S } & \multirow[b]{2}{*}{ Longitude E } & \multirow[b]{2}{*}{ Year $^{\mathrm{a}}$} & \multirow[b]{2}{*}{ No. of PSPs ${ }^{b}$} & \multicolumn{2}{|c|}{ Number of increments } \\
\hline & & & & & Predetection & Post detection \\
\hline Ashley & $43^{\circ} 11^{\prime}$ & $172^{\circ} 35^{\prime}$ & 1973 & 23 & 1 & 83 \\
\hline Berwick & $45^{\circ} 58^{\prime}$ & $169^{\circ} 53^{\prime}$ & $1981^{*}$ & 6 & 2 & 9 \\
\hline Blue mountain & $45^{\circ} 54^{\prime}$ & $169^{\circ} 22^{\prime}$ & $1979 *$ & 29 & 47 & 98 \\
\hline Craigieburn & $43^{\circ} 06^{\prime}$ & $171^{\circ} 52^{\prime}$ & $1990 *$ & 12 & 1 & 59 \\
\hline Geraldine & $44^{\circ} 05^{\prime}$ & $171^{\circ} 04^{\prime}$ & $1973^{*}$ & 5 & 0 & 16 \\
\hline Glenfoyle & $44^{\circ} 44^{\prime}$ & $169^{\circ} 20^{\prime}$ & $2000^{*}$ & 4 & 12 & 12 \\
\hline Golden Downs East & $41^{\circ} 29^{\prime}$ & $172^{\circ} 54^{\prime}$ & 1969 & 31 & 33 & 151 \\
\hline Golden Downs West & $41^{\circ} 33^{\prime}$ & $172^{\circ} 45^{\prime}$ & 1969 & 26 & 22 & 113 \\
\hline Granville & $42^{\circ} 19^{\prime}$ & $171^{\circ} 38^{\prime}$ & 1974 & 2 & 4 & 4 \\
\hline Hanmer & $42^{\circ} 31^{\prime}$ & $172^{\circ} 52^{\prime}$ & 1978 & 7 & 30 & 8 \\
\hline Herbert & $45^{\circ} 18^{\prime}$ & $170^{\circ} 45^{\prime}$ & 1981 & 11 & 16 & 10 \\
\hline Hochstetter & $42^{\circ} 28^{\prime}$ & $171^{\circ} 38^{\prime}$ & $1974 *$ & 2 & 0 & 3 \\
\hline Hokonui & $46^{\circ} 06^{\prime}$ & $168^{\circ} 34^{\prime}$ & 1977 & 8 & 12 & 11 \\
\hline Kaingaroa & $38^{\circ} 35^{\prime}$ & $176^{\circ} 33^{\prime}$ & 1959 & 52 & 63 & 364 \\
\hline Karioi & $39^{\circ} 26^{\prime}$ & $175^{\circ} 36^{\prime}$ & 1961 & 3 & 7 & 15 \\
\hline Longwood & $46^{\circ} 10^{\prime}$ & $167^{\circ} 57^{\prime}$ & 1980 & 20 & 23 & 27 \\
\hline Mahinapua & $42^{\circ} 47^{\prime}$ & $170^{\circ} 57^{\prime}$ & $1976^{*}$ & 2 & 2 & 3 \\
\hline Mangatu & $38^{\circ} 13^{\prime}$ & $177^{\circ} 53^{\prime}$ & 1971 & 1 & 0 & 6 \\
\hline Naseby & $45^{\circ} 01^{\prime}$ & $170^{\circ} 06^{\prime}$ & 1989 & 4 & 9 & 4 \\
\hline Ngaumu & $41^{\circ} 07^{\prime}$ & $175^{\circ} 57^{\prime}$ & $1971^{*}$ & 4 & 0 & 4 \\
\hline Omihi & $43^{\circ} 02^{\prime}$ & $172^{\circ} 53^{\prime}$ & 1979 & 3 & 0 & 6 \\
\hline Patunamu & $38^{\circ} 55^{\prime}$ & $177^{\circ} 13^{\prime}$ & 1970 & 2 & 0 & 14 \\
\hline Pureora & $38^{\circ} 32^{\prime}$ & $175^{\circ} 33^{\prime}$ & 1969 & 13 & 1 & 44 \\
\hline Rai valley & $41^{\circ} 10^{\prime}$ & $173^{\circ} 32^{\prime}$ & 1970 & 7 & 2 & 19 \\
\hline Scion grounds & $38^{\circ} 09^{\prime}$ & $176^{\circ} 16^{\prime}$ & $1959 *$ & 1 & 0 & 5 \\
\hline Silverpeaks & $45^{\circ} 44^{\prime}$ & $170^{\circ} 31^{\prime}$ & 1982 & 5 & 3 & 7 \\
\hline South Is. High Country & $44^{\circ} 23^{\prime}$ & $169^{\circ} 49^{\prime}$ & $1991 *$ & 5 & 6 & 6 \\
\hline Victoria S.F.P. & $42^{\circ} 09^{\prime}$ & $171^{\circ} 52^{\prime}$ & $1973 *$ & 14 & 0 & 76 \\
\hline Watt $\mathrm{T}$. & $45^{\circ} 54^{\prime}$ & $168^{\circ} 23^{\prime}$ & $1988^{*}$ & 1 & 0 & 3 \\
\hline Whakarewarewa & $38^{\circ} 11^{\prime}$ & $176^{\circ} 17^{\prime}$ & 1959 & 9 & 11 & 31 \\
\hline Totals & $\ldots$ & $\ldots$ & $\ldots$ & 312 & 307 & 1,211 \\
\hline
\end{tabular}
detection date of $P$. gaeumannii in the forest from the midpoint of the increment. Therefore, this factor had 41 levels ranging from

TABLE 1. Description of data used for modeling the impact of Phaeocryptopus gaeumannii on Douglas-fir plantations

a Year detected: * indicates date inferred from records in nearby forests.

b PSPs = permanent sample plots. 
-10 (representing 10 years prior to detection) to 30 (30 years after detection).

Also included in the model were other variables which might influence growth rate. In particular, because, within any PSP, increments made prior to detection were of necessity younger than those made following detection, it was important to include age in the model, because otherwise the reduction in growth rate with age that occurs naturally in older stands would bias the estimated effect of the disease. Other variables that might influence growth rates included stocking and local differences in site productivity. Effects of age and stocking were incorporated using a quadratic surface in age measured at the midpoint of each interval and stocking measured at the start of the interval. Local site productivity was accommodated by including random effects for each PSP in the model.

Therefore, the mixed models, including all of the above variables and factors, were of the following form:

$$
\operatorname{Yinc}_{i t}=\alpha_{0}+\alpha_{1} T_{i t}+\alpha_{2} N_{i t}+\alpha_{3} T_{i t}^{2}+\alpha_{4} N_{i t}^{2}+\alpha_{5} T_{i t} N_{i t}+D_{t}+P_{i}+e_{i t}
$$

where Yinc $_{i t}$ is the growth increment (MTH, BA, or volume) in the $i$ th plot, $t$ years after detection of $P$. gaeumannii (values of $t$ in the data set ranged between -10 and 30), $T_{i t}$ is age in years, $N_{i t}$ is stocking in stems ha- ${ }^{-1}, \alpha_{k}$ are coefficients of a quadratic surface in age and stocking, $D_{t}$ is a fixed-effect term representing the effect of the disease on the growth increment $t$ years after detection, $P_{i}$ is a random-effect term for the $i$ th plot, and $e_{i t}$ is a random error term.

The least squares means obtained from these models for the factor $D$ represent the estimated average growth rate for any year from 10 years prior to detection to 30 years following detection, adjusted for the effects of stand age and stocking. It was expected that the adjusted growth rate would be constant during the 10 years prior to detection, exhibit a decline during some period of years following detection, and eventually level off at a constant rate lower than the preinfection level. The following step-change function, which assumes an initial constant adjusted growth rate followed by a linear decline, which then reverts to a constant lower rate, was therefore fitted to the least squares means obtained from model 5 as:

$$
\begin{aligned}
\text { AdjYinc }_{t} & =\text { Yinc }_{0}, & & t \leq T_{0} \\
& =\left[\operatorname{Yinc}_{0}\left(t-T_{1}\right)-\operatorname{Yinc}_{1}\left(t-T_{0}\right)\right] /\left(T_{0}-T_{1}\right), & & T_{0}<t<T_{1} \\
& =\operatorname{Yinc}_{0}, & & t \geq T_{1}
\end{aligned}
$$

where, AdjYinc is $_{t}$ the growth rate adjusted for age and stocking $t$ years after detection of $P$. gaeumannii, Yinc $_{0}$ is the preinfection adjusted growth rate, $Y_{i n c} c_{1}$ is the eventual postinfection adjusted growth rate, $T_{0}$ is the time from detection when the growth rate begins to decline linearly, and $T_{1}$ is the time from detection when the decline ceases. This function was fitted to the least squares means from model 5 weighting by the inverse of the squared standard errors, using the SAS (version 9.1) NLIN procedure. The percent reduction in growth rate attributable to the disease can be estimated as $100 \times\left(\right.$ Yinc $_{0}-$ Yinc $) /$ Yinc $_{0}$.

An alternative to model 5 was then used to test whether the decline in growth rate due to $P$. gaeumannii was influenced by any environmental factor. To achieve this, model 5 was modified by assuming that the growth rate declined linearly for 15 years from the time of detection. To fit this model, for all preinfection increments the variable $t$ was assigned a value of zero, and increments $>15$ years after detection were excluded from the analysis. The modified model had the following form:

$$
\begin{gathered}
\text { Yinc }_{i t}=\alpha_{0}+\alpha_{1} T_{i t}+\alpha_{2} N_{i t}+\alpha_{3} T_{i t}{ }^{2}+\alpha_{4} N_{i t}{ }^{2}+\alpha_{5} T_{i t} N_{i t}+\beta_{1} t+ \\
\beta_{2} t x+\beta_{3} t x^{2}+P_{i}+e_{i t}
\end{gathered}
$$

where the annual rate of decline in the 15 years following detection is expressed as a function of the environmental variable $x$ by the quadratic function $\beta_{1}+\beta_{2} x+\beta_{3} x^{2}$. To assess the significance of this quadratic response for each climatic variable, likelihoodratio tests $\left(\chi^{2}\right.$ test with two degrees of freedom) were calculated as twice the difference in the log likelihoods of model 7 and the same model fitted without the $\beta_{2}$ and $\beta_{3}$ terms.

To quantify the economic impact of growth losses due to the disease, it is necessary to understand how reductions in growth rate are likely to affect the various costs and returns from a typical Douglas-fir forest in New Zealand. An integrated forest modeling system, the Douglas-fir Calculator (27), was used for this purpose. This Excel-based program includes a stand-level national growth model, a log-making algorithm, and financial analysis functions. It enables forest managers to estimate harvest volume by log grade, and calculates the financial return expressed as a net present value (NPV) at the time of establishment in New Zealand dollars per hectare, with the facility to vary management inputs, costs, and log values. There is also the facility to vary site productivity using both the Site Index (defined as MTH at age 40 years) and the 500 Index (an index of volume productivity representing the volume mean annual increment for a typical regime) (22).

To demonstrate the effect of a disease causing a reduction in growth rate, the Douglas-fir Calculator (version 3.0) was initially run using default settings which are typical of a current Douglasfir stand in New Zealand, and was then rerun using the same regime, costs, and log prices but with the Site Index and 500 Index increased to represent hypothetical preinfection productivity levels based on the estimated growth decline from model 6 . The difference in NPV between these two runs represents the expected loss in value attributable to the reduced growth rate. Note that most of the financial inputs for the two runs do not change (e.g., establishment and management costs, land value, and so on); therefore, these have no impact on the calculation. The important factors are the value of the harvested logs and the costs of harvesting, which are both reduced by growth loss.

\section{RESULTS}

A simple analysis of the stem volume increments using quadratic response curves showed that stem volume current annual increment (CAI) for Douglas-fir in New Zealand tends to peak at an age of $\approx 30-35$ years, with the peak CAI averaging $\approx 40 \mathrm{~m}^{3} \mathrm{ha}^{-1}$ year ${ }^{-1}$ before detection and $30 \mathrm{~m}^{3} \mathrm{ha}^{-1}$ year $^{-1}$ after detection (Fig. 1). Reductions in mean increment adjusted for age following detection are also apparent for MTH and BA.

When model 5 was fitted to the growth data, it revealed a clear decline in growth rate in the years following detection of $P$. gaeumannii, with the factor $D$ representing time from detection being statistically highly significant for all growth variables (type $3 F$ values of 5.91, 6.22, and 7.34 for volume, MTH, and BA CAI respectively; $P<0.0001$ in all cases). The least squares means for $D$ giving growth rates for volume, MTH, and BA adjusted for age and stocking for each whole year from 10 years prior to 30 years after detection of $P$. gaeumannii showed a very clear pattern (Fig. 2 ). In the 10 years prior to detection, adjusted growth rates were approximately constant but a steady decline began at approximately the time of detection, with the growth rate eventually stabilizing at a constant but lower level 14 to 20 years after detection.

This pattern was well described by model 6 and parameter estimates for this model are given in Table 2, both for all of New Zealand and separately for the North and South Islands. The estimated reductions between the predetection growth rate and the eventual stable level reached some years after detection for all New Zealand were $25 \%$ for MTH, 27\% for BA, and 32\% for stem volume. Growth reduction was greater for the North Island than 
the South Island. Based on Douglas-fir Calculator runs, the estimated declines in stem volume growth of 35 and $23 \%$ for the North and South Islands, respectively, equate to losses in NPV at the time of establishment of $\$ N Z 2,620$ and 1,470 ha $\mathrm{ha}^{-1}$, respectively, using a discount rate of $6 \%$. These values are very sensitive to the discount rate, increasing to $\$ N Z 6,980 \mathrm{ha}^{-1}$ (North Island) and \$NZ3,930 ha ${ }^{-1}$ (South Island) using a discount rate of 4\%, and decreasing to \$NZ1,060 ha ${ }^{-1}$ (North Island) and \$NZ590 ha ${ }^{-1}$ (South Island) using a discount rate of $8 \%$.
For all growth variables, the initial decline began at approximately the year of detection, with $T_{0}$ in model 6 not differing significantly from zero for any growth variable except for MTH CAI in the North Island. where the decline began 4 years after detection. The estimated duration of the decline for all New Zealand was 14 years for BA and volume and 18 years for MTH; however, generally slightly shorter decline periods for BA and volume were estimated when the data from each island was analyzed separately (Table 2). Mortality, expressed as a percent
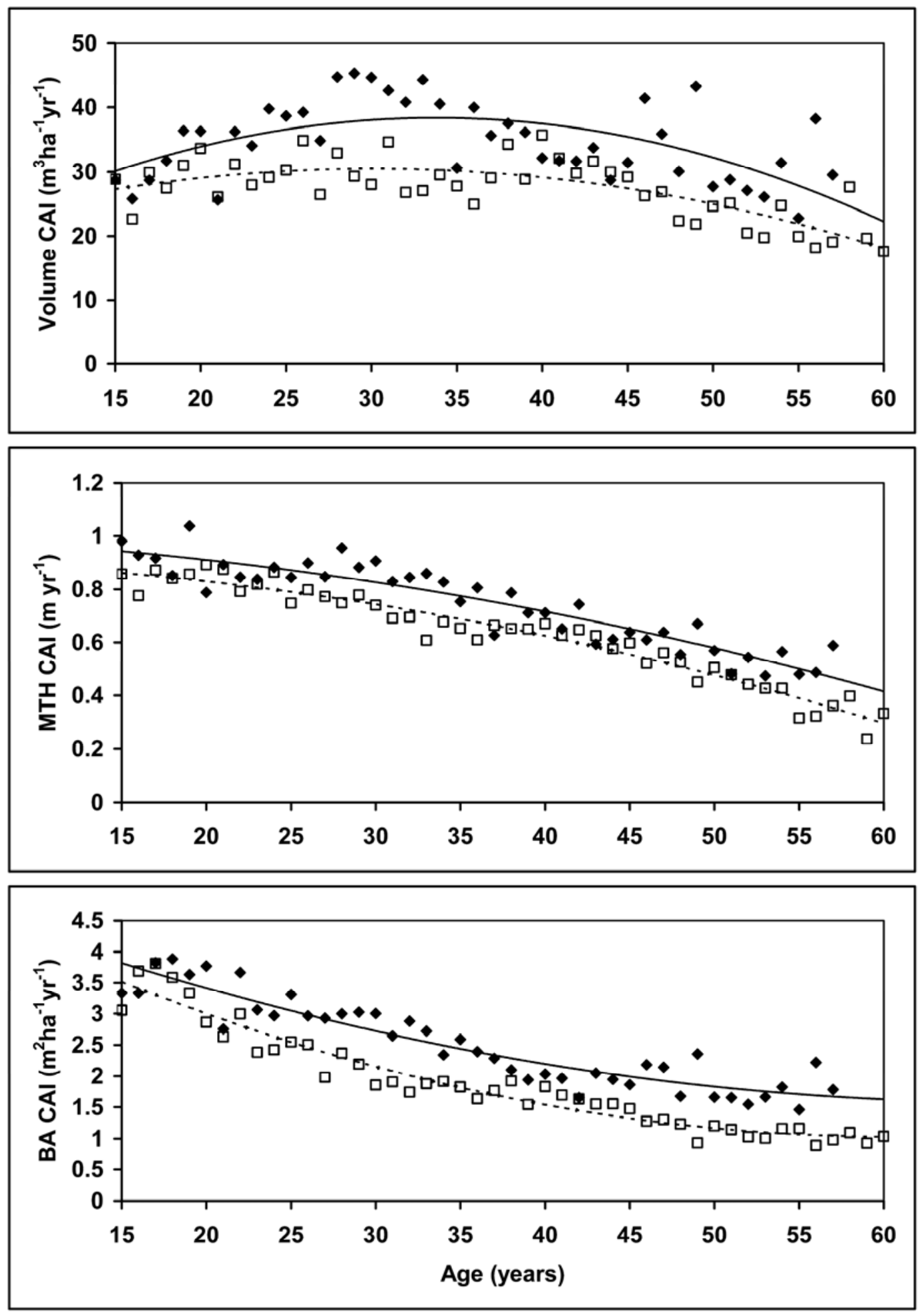

Fig. 1. Stem volume, mean top height (MTH), and basal area (BA) increments versus age averaged for each whole year for measurements made prior to (diamonds, solid line) and following (squares, dashed line) detection of Phaeocryptopus gaeumannii. CAI = current annual increment. Lines show fitted quadratic response functions. 
annual loss in stem volume (Fig. 3), averaged $2.0 \mathrm{~m}^{3} \mathrm{ha}^{-1}$ year $^{-1}$ prior to detection and $2.3 \mathrm{~m}^{3} \mathrm{ha}^{-1}$ year $^{-1}$ following detection; however, this minor increase in mortality of $0.3 \mathrm{~m}^{3} \mathrm{ha}^{-1}$ year ${ }^{-1}$ was not statistically significant $\left(F_{1,1287}=1.0, P=0.32\right)$. Clearly, by far the major effect of the disease was to reduce growth rates of living trees rather than to cause an increase in mortality, with age/stocking adjusted gross volume CAI decreasing from 33.6 to $22.9 \mathrm{~m}^{3} \mathrm{ha}^{-1}$ year $^{-1}$, a reduction of $10.7 \mathrm{~m}^{3} \mathrm{ha}^{-1}$ year $^{-1}$.
The impact of the disease on growth was greater in the North Island than the South Island (Fig. 4; Table 2), suggesting that climatic factors might be affecting the severity of its impact. To explore this issue, climatic variables were tested using model 7. This analysis demonstrated a strong association between temperature and volume growth decline, with the decline generally being greater on warmer sites. For all temperature variables, the quadratic term in model 7 was statistically significant, indicating
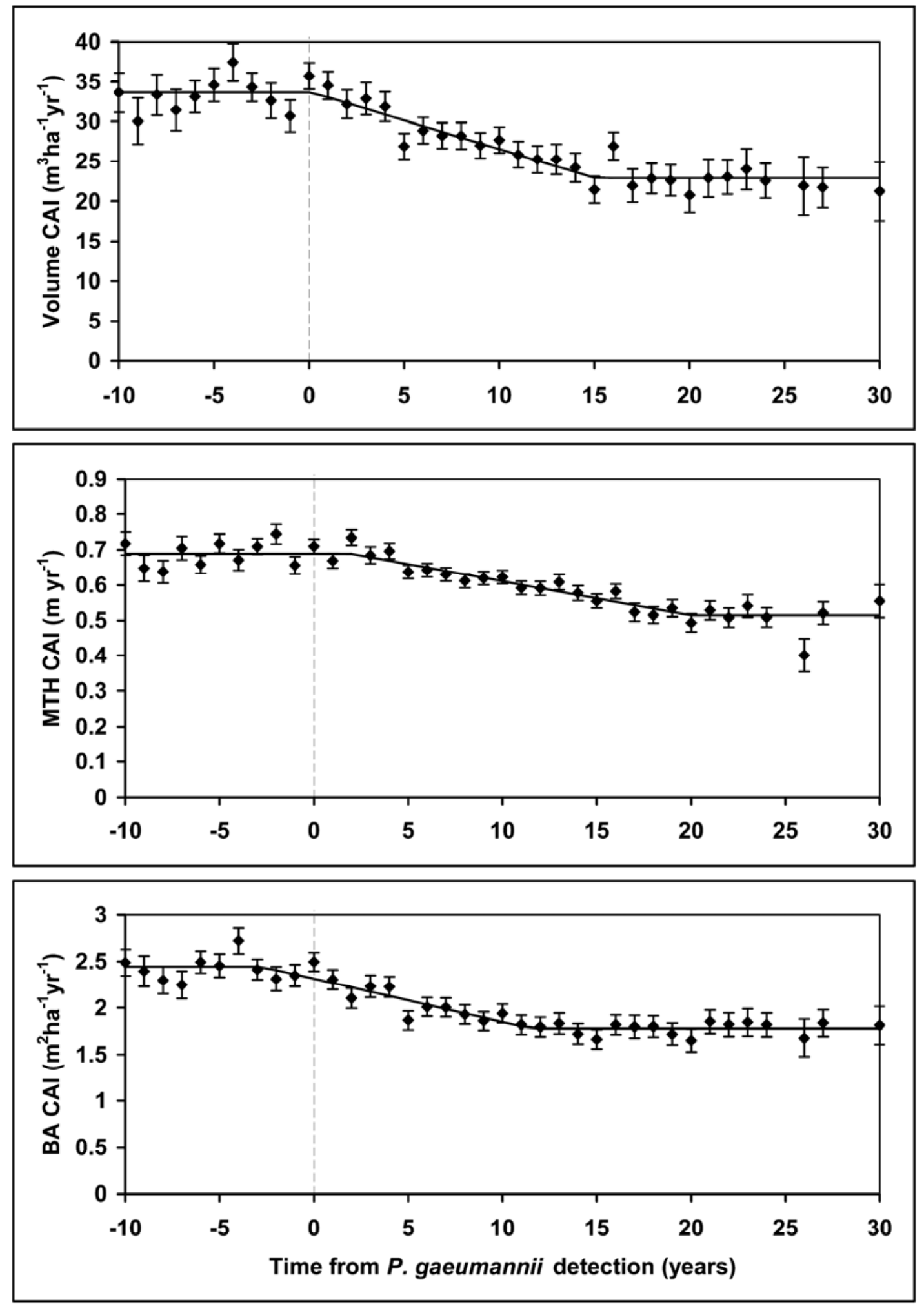

Fig. 2. Volume, mean top height (MTH), and basal area (BA) increment adjusted for age and stocking versus time since detection of Phaeocryptopus gaeumannii in whole years. Values shown are least squares means from model 5 with standard errors. CAI $=$ current annual increment. Fitted lines are from model 6. 
a nonlinear response. Likelihood-ratio tests used to indicate the strength of the relationship for each variable (Fig. 5) showed that the strongest relationships were for minimum daily temperature in late spring, with $\chi^{2}$ statistics of $53.4,49.8$, and 45.1 for the Southern Hemisphere late-spring and early-summer months of October, November, and December, respectively. Minimum daily temperatures in other months were more weakly associated with growth decline, with the lowest $\chi^{2}$ statistic being 10.9 for June daily minimum temperature. The relationship between volume growth decline and October minimum daily temperature is shown in Figure 6. Average monthly temperatures generally had slightly weaker relationships with growth decline than spring minimum temperature, with the strongest relationship being for October mean temperature $\left(\chi^{2}=43.7\right)$. The likelihood-ratio test for mean annual temperature had a $\chi^{2}$ statistic of 35.9.

After fitting linear and quadratic terms for October mean daily minimum temperature in model 7, mean annual rainfall was tested as a secondary environmental variable and found to be statistically significant $\left(F_{1,275}=12.31, P=0.0005\right)$, with less growth decline on wetter sites at the same temperature. Rainfall for all individual months was less significant than annual rainfall. Table 3 gives parameter estimates from model 7 for predicting annual volume growth rate decline in the 15 years following infection using a quadratic function of October minimum daily temperature model with and without a linear annual rainfall term, and a quadratic function of June average temperature for comparison with needle infection models developed using winter mean temperature $(33,53)$. The October minimum daily temperature model indicates that no growth decline occurred at $<3.2^{\circ} \mathrm{C}$, while maximum growth decline occurred at $5.4^{\circ} \mathrm{C}$. On average,

TABLE 2. Estimates of model 6 parameters with standard errors in parentheses $^{\mathrm{a}}$

\begin{tabular}{lccr}
\hline Variable, data $^{\mathrm{b}}$ & Reduction $(\%)$ & $T_{0}$ & $T_{0}-T_{1}$ \\
\hline Volume CAI & & & \\
$\quad$ All New Zealand & $31.9(1.9)$ & $0.2(1.3)$ & $14.9(2.2)$ \\
North Island & $34.6(2.2)$ & $3.0(1.6)$ & $11.9(2.6)$ \\
$\quad$ South Island & $22.9(2.2)$ & $0.1(1.7)$ & $8.4(2.7)$ \\
MTH CAI & & & \\
All New Zealand & $25.4(2.0)$ & $2.0(1.4)$ & $17.9(2.6)$ \\
North Island & $27.0(1.6)$ & $3.9(1.2)$ & $13.7(2.0)$ \\
South Island & $22.8(3.7)$ & $1.8(2.1)$ & $18.9(4.6)$ \\
BA CAI & & & \\
All New Zealand & $27.3(1.6)$ & $-2.8(1.4)$ & $14.3(1.6)$ \\
North Island & $35.5(2.0)$ & $1.3(1.3)$ & $10.1(2.0)$ \\
South Island & $19.5(2.0)$ & $-0.5(1.3)$ & $5.4(2.4)$ \\
\hline
\end{tabular}

a Also shown is the modeled percentage reduction in growth increments attributable to Phaeocryptopus gaeumannii.

${ }^{\mathrm{b}}$ Growth variables: $\mathrm{CAI}=$ current annual increment, $\mathrm{MTH}=$ mean top height, and $\mathrm{BA}=$ basal area.



Fig. 3. Mortality rate adjusted for age and stocking versus time since detection of Phaeocryptopus gaeumannii in whole years. Values shown are least squares means from model 5 with standard errors. the PSPs in the lowest quintile of October minimum daily temperature $\left(2.5\right.$ to $\left.3.9^{\circ} \mathrm{C}\right)$ suffered no loss in growth (Fig. 6). Note that, although this analysis suggests that growth decline attained a maximum at $5.4^{\circ} \mathrm{C}$, the apparent reduction in growth decline at temperatures greater than this (Fig. 6) is not statistically significant and is likely only to be an artifact of the quadratic model. A map showing the spatial variation of the predicted loss in volume CAI 15 years after the arrival of the disease (Fig. 7)

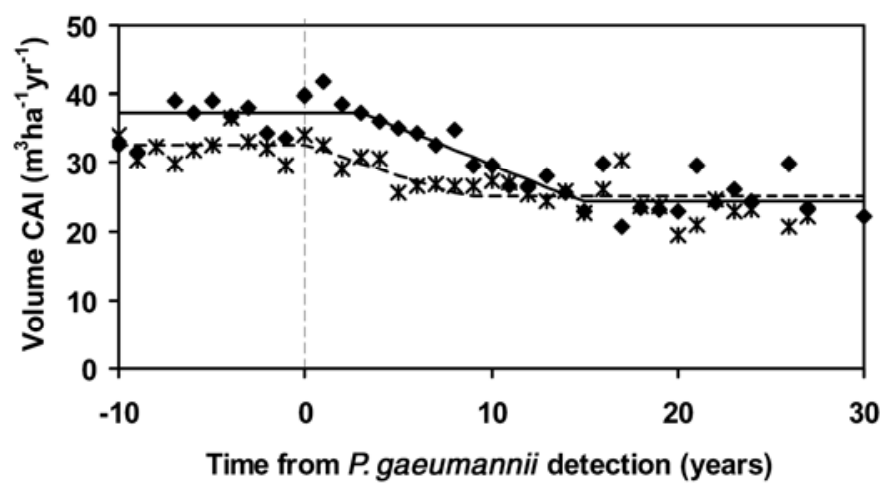

Fig. 4. Volume current annual increment (CAI) adjusted for age and stocking versus time since detection of Phaeocryptopus gaeumannii in whole years for North Island (diamonds, solid line) and South Island (asterisks, dashed line). Form of the fitted line shown is described in the text by model 6.

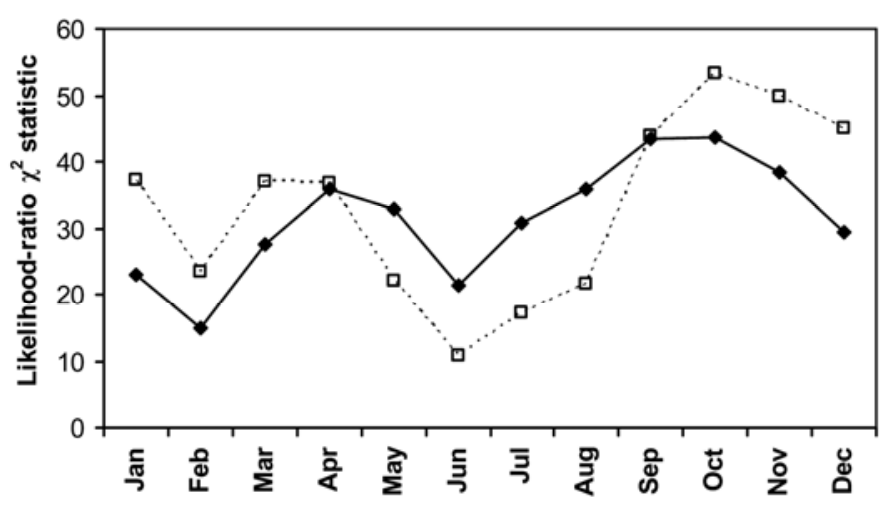

Fig. 5. Likelihood-ratio $\chi^{2}$ statistics testing the association between growth decline due to Phaeocryptopus gaeumannii and monthly means of daily mean temperature (solid line) and daily mean minimum temperature (dashed line) obtained using model 7.

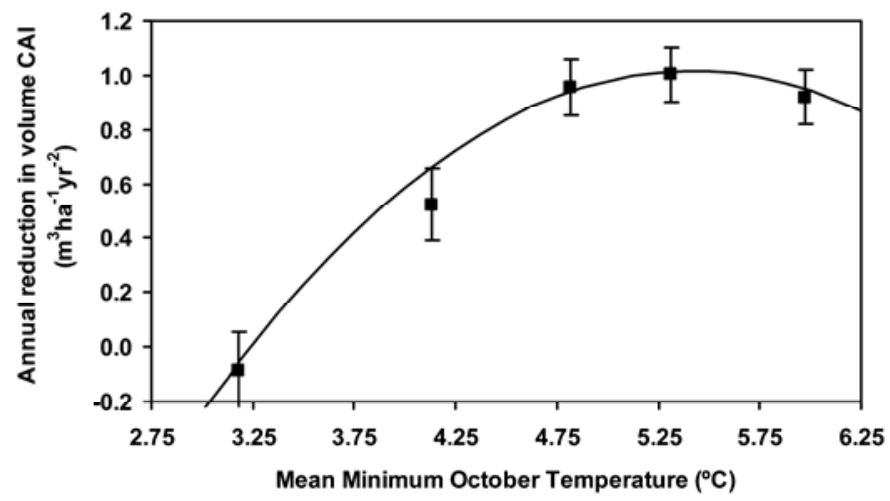

Fig. 6. Annual reduction in volume current annual increment (CAI) adjusted for age and stocking in the 15 years following detection of Phaeocryptopus gaeumannii versus mean minimum daily temperature in October generated from a quadratic surface using model (a) from Table 3. Also shown are means and standard errors for quintiles of October minimum daily temperature $(2.5$ to $3.9,3.9$ to $4.5,4.5$ to $5.2,5.2$ to 5.5 , and 5.5 to $7.8^{\circ} \mathrm{C}$ ). 
indicates that most of the North Island and the coastal plains of the northern South Island suffered reductions of $>10 \mathrm{~m}^{3} \mathrm{ha}^{-1}$ year $^{-1}$, while coastal southern South Island and elevated areas in the North Island and northern South Island suffered losses of 5 to $10 \mathrm{~m}^{3} \mathrm{ha}^{-1}$ year $^{-1}$. Some cooler inland areas in the South Island are predicted to have suffered losses of $<5 \mathrm{~m}^{3} \mathrm{ha}^{-1} \mathrm{year}^{-1}$.

After extending model 7 to include both October minimum daily temperature and rainfall, interaction terms between time since detection and age and stocking were also added to the model. However, neither term was statistically significant (age: $F_{1,275}=$ $2.29, P=0.13$; stocking: $F_{1,275}=1.74, P=0.19$ ), indicating that growth decline did not vary with either age or stocking.

\section{DISCUSSION}

Combining growth data from a network of several hundred PSPs with precise information on the timing of the first appearance of the Swiss needle cast pathogen in each forest within New Zealand provided a unique data set for quantifying the decline in growth caused by the disease by comparing before and after growth rates. Studies of growth decline undertaken after the disease has become established or where it is endemic are more challenging because it is difficult to compare growth rates in the disease-free and diseased states directly and, therefore, such studies must rely on exploring associations between growth rate and crown health (28). Although several studies assessed growth losses following the initial appearance of the disease in various European forests and elsewhere, these were generally based on small samples of individual tree measurements, and therefore, do not provide reliable estimates of average growth decline. In comparison, our study uses data from a network of plots closely representative of the national estate of Douglas-fir in New Zealand at the time the disease arrived.

This study indirectly supports the role of $P$. gaeumannii as a primary pathogen of Douglas-fir $(13,30,55)$, and determined that the average decline in stem volume growth rate following the establishment of the disease in New Zealand was a little over $>30 \%$, somewhat greater in the North Island, and significantly less in the South Island. This level of volume growth decline is comparable with the average for coastal Oregon of $23 \%$ found by Maguire et al. (28). Average decline in stem volume growth rates for plots within a particular forest began at approximately the time the disease was first detected in the forest, and generally continued for a period of 8 to 15 years before the growth rate stabilized at a lower level. This period of decline presumably reflects the length of time the pathogen typically took, first to spread throughout a forest and, having done so, then to reach maximum intensity. For example, in Kaingaroa Forest, symptoms of the disease appeared to take several years to spread from northern to southern areas of the forest (20), and across the entire country, $P$. gaeumannii took $>30$ years to spread to all significant forests (Table 1). Also, after first being detected in Lismore Forest in the southern North Island, infection was then observed to take 4 to 5 years to reach full intensity (54).

The relationship between growth decline and temperature found in this study is in general agreement with several previous studies, although it differs somewhat in identifying minimum daily temperature in late spring as the most important climatic variable. In Oregon, mean winter temperature was determined as the variable most closely related to needle infection $(33,52)$. In New Zealand, Stone et al. (53) found minimum temperature in winter to be the variable that was most strongly correlated, although other temperature variables also correlated well with needle infection. On the other hand, spring and summer temperature was more closely related to growth loss of Douglas-fir in Oregon (1), which agrees with the outcome of this study. Some disparity in the relationship with season is not unexpected given the different methodologies used. It may also indicate that, whereas winter temperatures affect mycelial development within the infected needles, the impact of infection on tree growth is influenced more by minimum temperatures during late spring and early summer. This is when the occlusion of stomata by pseudothecia in needles older than 1 year may have its maximum effect, just when the photosynthetic requirement for gas exchange is likely to be greatest $(32,51)$. Other factors, such as the demand for available water, may also impact most during the growing season, especially in lower-rainfall areas, possibly influenced by the effect of stomatal occlusion on the uptake of water via the transpiration stream (see below). However, it is interesting that, when we used June mean temperature as the predictor variable (Table 3, third model), the threshold temperature below which no growth loss is predicted is $3.0^{\circ} \mathrm{C}$. This is identical to the temperature at which needle infection is predicted to be zero by the independently derived model of Stone et al. (53), which is also based on New Zealand data and uses the same predictor, and very similar to the limiting winter temperature found in Oregon (33). Therefore, there is good evidence from all three studies that the disease has minimal impact on either needle infection or growth at winter mean temperatures $<3.0^{\circ} \mathrm{C}$, although we would argue from our analysis that a slightly better threshold in New Zealand is provided by an October minimum daily temperature of $3.2^{\circ} \mathrm{C}$.

The historic relationship between growth decline and temperature identified in this study has a number of implications regarding potential effects of climate change. Importantly, as also found by Stone et al. (52), the analysis reveals that quite a small increase in temperature can result in a dramatic increase in the severity of the disease. For example, an increase of $1{ }^{\circ} \mathrm{C}$ from the $3.2^{\circ} \mathrm{C}$ October minimum daily temperature threshold below which it has negligible impact on growth is predicted to result in $68 \%$ of its maximum effect on growth, while an increase of $2^{\circ} \mathrm{C}$ is predicted to cause $99 \%$ of maximum growth loss. On the other hand, the model predicts no further decrease in growth if October minimum daily temperature increases beyond $5.2^{\circ} \mathrm{C}$. Furthermore, although the arrival of the disease caused a considerable decline in Douglas-fir growth rate in New Zealand, it did not cause any significant increase in mortality. Therefore, although the disease has had a dramatic impact on the performance of the species in New Zealand, it still continues to be considered a viable forestry species even on sites that are well above the temperature threshold.

As noted above, Hood (14) found a reduction in percent infection in British Columbia on sites with low late-spring rainfall,

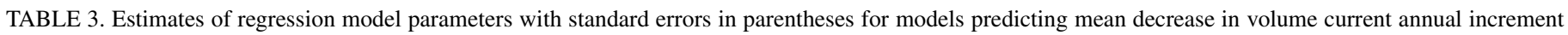
$\left(\mathrm{m}^{3} \mathrm{ha}^{-1}\right.$ year $\left.^{-1}\right)$ in the 15 years following detection as a function of various climatic variables ${ }^{\mathrm{a}}$

\begin{tabular}{|c|c|c|c|}
\hline \multirow[b]{2}{*}{ Model term } & \multicolumn{3}{|c|}{ Model } \\
\hline & $\mathrm{a}$ & $\mathrm{b}$ & $\mathrm{c}$ \\
\hline Intercept & $-5.27(0.78)$ & $-3.84(0.90)$ & $-3.11(0.65)$ \\
\hline Linear temperature & $2.32(0.33)$ & $2.00(0.35)$ & $1.40(0.24)$ \\
\hline Quadratic temperature & $-0.214(0.034)$ & $-0.177(0.037)$ & $-0.119(0.023)$ \\
\hline Rainfall & ... & $-5.52 \times 10^{-4}\left(1.58 \times 10^{-4}\right)$ & $\ldots$ \\
\hline
\end{tabular}

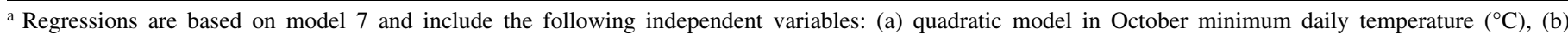
quadratic model in October minimum daily temperature $\left({ }^{\circ} \mathrm{C}\right)$ with linear annual rainfall ( $\mathrm{mm}$ year ${ }^{-1}$ ), and $(\mathrm{c})$ quadratic model in mean June temperature $\left({ }^{\circ} \mathrm{C}\right.$ ). 
and Oregon studies have demonstrated an association between disease severity and summer fog or spring leaf wetness. Therefore, the negative association between rainfall and growth loss due to the disease found in our study was unexpected. However, a number of points regarding this can be made. First, even at the driest sites, spring rainfall in New Zealand is much higher than the $P$. gaeumannii-limiting threshold in British Columbia of
$110 \mathrm{~mm}$ of May to July rainfall. In the equivalent Southern Hemisphere period (November to January), the lowest rainfall for any plot in our study is $160 \mathrm{~mm}$ and the average is $770 \mathrm{~mm}$. Therefore, unlike British Columbia, spring rainfall is never a limiting factor in New Zealand. Second, because this was an observational study, it is quite possible that the negative association between rainfall and growth decline is not causative but

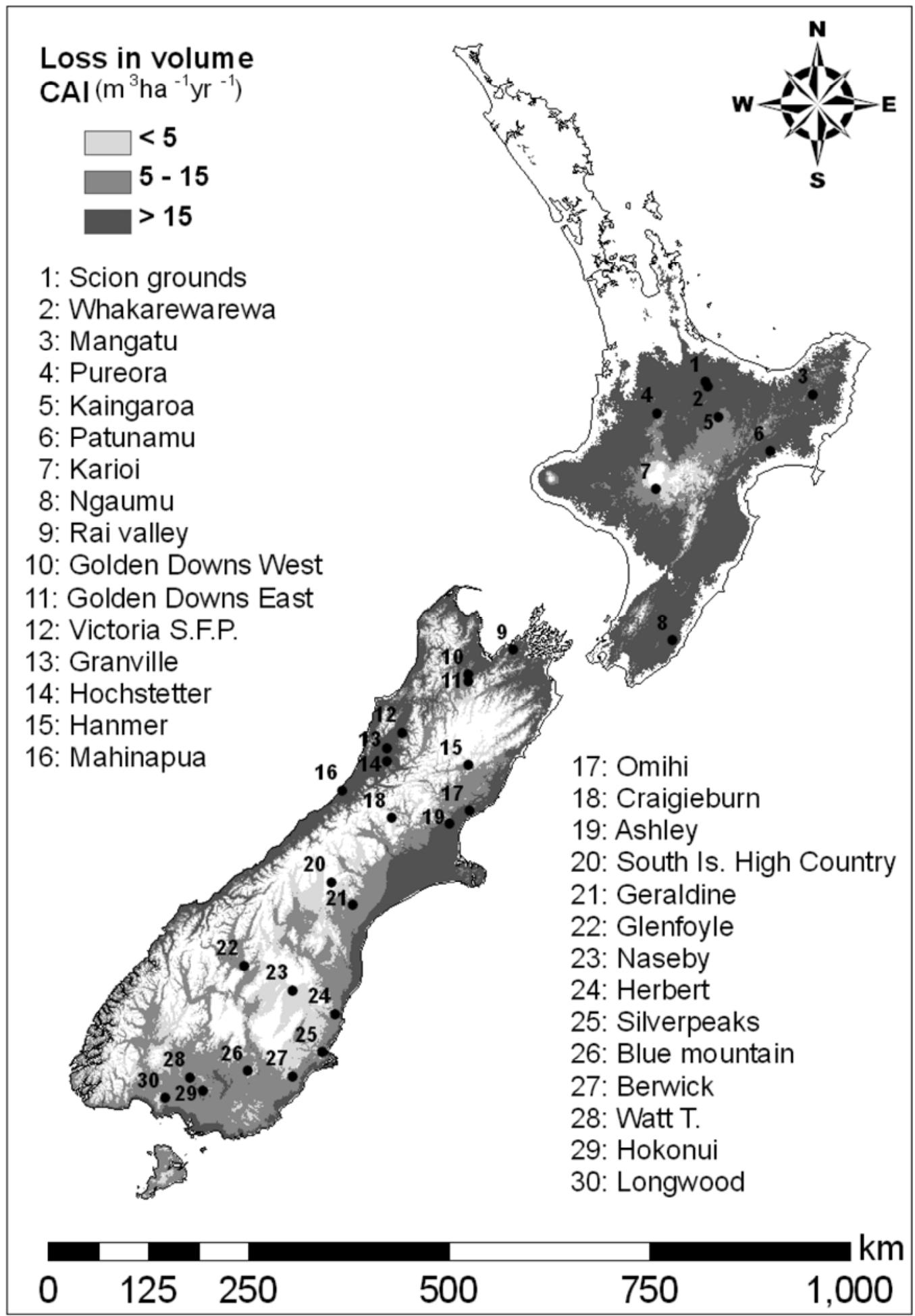

Fig. 7. Map of New Zealand showing the locations of forests used in the study and the predicted spatial variation of loss in volume current annual increment (CAI) 15 years after the arrival of Swiss needle cast. The surface was obtained by multiplying by 15 the annual loss in CAI predicted by applying Model (a) in Table 3 to a GIS surface of October daily minimum temperature (24). Locations warmer than the temperature corresponding to predicted maximum loss $\left(15.3 \mathrm{~m}^{3} \mathrm{ha}^{-1} \mathrm{year}^{-1}\right.$ at $\left.5.4^{\circ} \mathrm{C}\right)$ are assumed to suffer maximum loss. Areas of the country outside the October daily minimum temperature range in the study $\left(2.3\right.$ to $\left.7.6^{\circ} \mathrm{C}\right)$ are left blank. 
rather due to some other concomitant factor associated with rainfall. Third, our analysis measures the direct effect of the disease on growth whereas most other studies have focused on infection and foliage health, and it is possible that similar levels of needle infection could cause greater growth decline on drier than wetter sites, as suggested above. A closer examination of the data indicates that this rainfall effect is largely caused by growth declines, higher than expected on the basis of temperature, in a number of low-rainfall forests in Canterbury, Otago, and Southland in the South Island (e.g., Ashley, Berwick, and Herbert forests, all with annual rainfall $<900 \mathrm{~mm}$ ). Other forests in these regions with higher rainfalls but comparable temperatures appear to have suffered little from the disease. An examination of the disease levels in these forests might help to better understand this issue.

This study enables a number of other aspects of the $P$. gaeumannii-induced growth decline in Douglas-fir to be examined in greater detail. There was considerable debate after the disease first appeared in New Zealand as to whether the growth decline was attributable to $P$. gaeumannii at all, or whether it was caused by $P$. gaeumannii in combination with other factors. It was widely believed that the effects of the disease might be exacerbated by overstocking, and that judicious thinning of affected stands might reduce these effects, and it was also suggested that the level of growth decline increased with stand age (20). However, the lack of a significant interaction between time since detection and either age or stocking on volume growth in model 7 implies that these views were largely unfounded and that, at any site, the level of growth loss due to the disease was similar regardless of stand age or stocking (17). However, because stand volume growth rates generally decrease at ages greater than $>40$ 50 years (Fig. 1), the reduction in growth rate may have been proportionately greater in older stands.

An idea of the total cost of the disease to the forestry sector in New Zealand can be obtained by multiplying the per-hectare estimates of loss in NPV for the North and South Islands by the areas currently planted in Douglas-fir $(83,000$ ha in the South Island and 27,000 ha in the North Island in 2009) (40). This gives estimated total losses of \$NZ515 million, 193 million, and 77 million for discount rates of 4,6 , and $8 \%$, respectively. These are considerable values considering that, although it is the second most-important species in New Zealand after Pinus radiata D. Don, only $\approx 6 \%$ of the total forest plantation area is planted in Douglas-fir. It is also likely that, if Phaeocryptopus gaeumannii had not spread to New Zealand, the better performance of disease-free Douglas-fir would have ensured it was more widely planted, meaning that the true costs of the disease may have been even greater than the above figures suggest.

There is an assumption in this calculation that current and future crops of Douglas-fir suffer and will continue to suffer a growth rate reduction in response to the disease similar to that which occurred historically when $P$. gaeumannii first arrived in New Zealand. However, there has been a significant change over time in the genetic composition of Douglas-fir grown in New Zealand, meaning that this assumption is not necessarily true. Extensive planting of Douglas-fir first occurred in the 1920s and 1930s using seed mostly imported directly from Washington State (59). Subsequent plantings made prior to 1965 were from seed collected from New Zealand stands and, therefore, are of Washington origin but presumably with significant adaptation to New Zealand conditions. Evaluation of provenance trials planted in New Zealand in the 1950 s showed that $30 \%$ faster growth rates could be achieved using provenances from the coastal Californian fog belt (59), and many stands established subsequent to 1970 have used seed from these origins. Mean annual increments of current New Zealand Douglas-fir stands appear similar to those established 80 years ago, which had the advantage of 30 or more years of growth prior to the arrival of the pathogen. Presumably, therefore, the negative effects of the disease have been largely offset by the faster growth rates of trees genetically better suited to New Zealand conditions.

What is not known is whether these better-performing trees have a similar level of tolerance to $P$. gaeumannii, and whether current Douglas-fir stands are suffering losses in growth similar to the $32 \%$ average reduction that occurred historically. This may be the case because observations from provenance trials suggest that, if anything, despite their superior growth rates, coastal Californian provenances have poorer needle retention scores than trees grown from New Zealand-sourced seed (16,59). Assuming that the historically observed effect of the disease on growth rate also applies to the current crop, then, in the absence of $P$. gaeumannii, Site Indices would average $>40 \mathrm{~m}$ compared with current typical values of $31 \mathrm{~m}$, while mean annual volume increments at typical rotations of 45 years would average $>26 \mathrm{~m}^{3}$ $\mathrm{ha}^{-1}$ year ${ }^{-1}$ compared with current averages of $\approx 18 \mathrm{~m}^{3} \mathrm{ha}^{-1}$ year ${ }^{-1}$. These figures suggest that average stands would be achieving growth rates that have probably hardly, if ever, been achieved by the species in New Zealand, even on optimum sites, and give some idea of the considerable loss to the New Zealand forest industry caused by the disease.

\section{ACKNOWLEDGMENTS}

This article is dedicated to Leith Knowles (deceased), who was the project's driving force and champion. The P. gaeumannii distribution data relied on samples collected and observations provided by the following Forest Biology Observers of the former Forest Biology Service: the late C. W. Barr, D. A. Bartram, P. M. Bradbury, D. Coates, G. I. Collett, the late F. H. Crockett, W. A. Holloway, D. J. Kershaw, R. M. J. McKenzie, R. J. Merrilees, B. J. Rogan, C. A. Scott, R. F. Thum, and A. Zandvoort. D. J. Palmer, and J. F. Gardner assisted technically. The PSP data were available only because of numerous measurements made over a considerable period by many unknown persons during the course of routine forestry inventory. The article has benefited from helpful comments by J. K. Stone, M. S. Watt, and an anonymous referee.

\section{LITERATURE CITED}

1. Black, B. A., Shaw, D. C., and Stone, J. K. 2010. Impacts of Swiss needle cast on overstory Douglas-fir forests of the western Oregon Coast Range. For. Ecol. Manage. 259:1673-1680.

2. Boyce, J. S. 1940. A needle-cast of Douglas fir associated with Adelopus gäumanni. Phytopathology 30:649-659.

3. Buchwald, N. F. 1940. Bør nye Douglasie-kulturer anlaegges i øjeblikket? [Should new Douglas fir plantings be established at the moment?]. Dan. Skovforen. Tidsskr. 25:521-527.

4. Delatour, C. 1997. Diseases in the forest. Europe. In: Compendium of Conifer Diseases. E. M. Hansen and K. J. Lewis, eds. The American Phytopathological Society, St. Paul, MN.

5. Durrieu, G. 1957. Influence du climat sur la biologie de Phaeocryptopus gäumanni (Rohde) Petrak, parasite du Pseudotsuga. C.R. Acad. Sci. 244:2183-2185.

6. Filip, G., Kanaskie, A., Littke, W., Browning, J., Hildebrand, D., and Maguire, D. 2007. Five-year impacts of Swiss needle cast on Douglas-fir in interior forests of Oregon, USA. Acta Silvatica Lignaria Hung. Special 23-29.

7. Ford, K. F., and Morton, H. L. 1971. Etiology, impact and distribution of Swiss needle cast of Douglas-fir in Michigan. (Abstr.) Phytopathology 61:1023.

8. Gäumann, E. 1930. Über eine neue Krankheit der Douglasien. Schweiz. Z. Forstwes. 81:63-67.

9. Gilmour, J. W. 1966. The pathology of forest trees in New Zealand. The fungal, bacterial and algal pathogens. In: New Zealand Forest Research Institute Technical Paper No. 48. New Zealand Forest Service, Wellington.

10. Goulding, C. J. 2005. Measurement of trees. In: NZIF Forestry Handbook. M. Colley, ed. New Zealand Institute of Forestry, New Zealand.

11. Hansen, E. M., Stone, J. K., Capitano B. R., Rosso, P., Sutton, W., Winton, L., Kanaskie, A., and McWilliams, M. G. 2000. Incidence and impact of Swiss needle cast in forest plantations of Douglas-fir in coastal Oregon. Plant Dis. 84:773-778.

12. Holm, F. 1940. Swiss needle cast of Douglas fir [in Danish]. Dan. Skovforen. Tidsskr. 25:583-584. 
13. Hood, I. A. 1977. Inoculation experiments with Phaeocryptopus gaeumannii on Douglas-fir seedlings. N.Z. J. For. Sci. 7:77-82.

14. Hood, I. A. 1982. Phaeocryptopus gaeumannii on Pseudotsuga menziesii in southern British Columbia. N.Z. J. For. Sci. 12:415-424.

15. Hood, I. A., and Kershaw, D. J. 1975. Distribution and infection period of Phaeocryptopus gaeumannii in New Zealand. N.Z. J. For. Sci. 5: 201-208.

16. Hood, I. A., and Kimberley, M. O. 2005. Douglas fir provenance susceptibility to Swiss needle cast in New Zealand. Australas. Plant Pathol. 34:57-62.

17. Hood, I. A., and Sandberg, C. J. 1979. Changes within tree crowns following thinning of young Douglas-fir infected by Phaeocryptopusgaeumannii. N. Z. J. For. Sci. 9:177-184.

18. Hood, I. A., Sandberg, C. J., Barr, C. W., Holloway, W. A., and Bradbury, P. M. 1990. Changes in needle retention associated with the spread and establishment of Phaeocryptopus-gaeumannii in planted Douglas-fir. Eur. J. For. Pathol. 20:418-429.

19. Hood, I. A., and van der Pas, J. B. 1979. Fungicidal control of Phaeocryptopus-gaeumannii infection in a 19-year-old Douglas-fir stand. N.Z. J. For. Sci. 9:272-283.

20. James, R. N., and Bunn, E. H. 1978. A review of Douglas fir in New Zealand. FRI Symp. No. 15. New Zealand Forest Research Institute, Rotorua, New Zealand.

21. Johnson, G. R., Gartner, B. L., Maguire, D., and Kanaskie, A. 2003. Influence of Bravo fungicide applications on wood density and moisture content of Swiss needle cast affected Douglas-fir trees. For. Ecol. Manage. 186:339-348.

22. Knowles, L. 2005. Development of a productivity index for Douglas-fir. N.Z. J. For. 50:19-22.

23. Lanier, L. 1966. Les maladies cryptogamiques du Douglas en France. Rev. For. Fr. 18:247-265.

24. Leathwick, J., Morgan, F., Wilson, G., Rutledge, D., McLeod, M., and Johnston, K. 2002. Land Environments of New Zealand: A Technical Guide. Ministry for the Environment, Wellington, and Manaaki Whenua Landcare Research, Hamilton, New Zealand.

25. Liese, J. 1938. Zur Frage des weiteren Anbaues der Douglasie in Deutschland unter Berücksichtigung der Adelopus-Nadelschütte. Mitt. Dtsch. Dendrol. Ges. 51:212-218.

26. Lunberg, J. 1952. Effects of injuries in 1947 upon the increment of Douglas fir [in Danish]. Dan.. Skovforens. Tidsskr. 37:467-472.

27. Maclaren, J. P., and Knowles, R. L. 2005. Version 2 Calculators. Upgrading the business of farm forestry. N.Z. Tree Grow. 26(2):24.

28. Maguire, D. A., Kanaskie, A., Voelker, W., Johnson, R., and Johnson, G. 2002. Growth of young Douglas-fir plantations across a gradient in Swiss needle cast severity. West. J. Appl. For. 17:86-95.

29. Mainwaring, D. B., Maguire, D. A., Kanaskie, A., and Brandt, J. 2005. Growth responses to commercial thinning in Douglas-fir stands with varying severity of Swiss needle cast in Oregon, USA. Can. J. For. Res. Rev. Can. Rech. For. 35:2394-2402.

30. Manter, D. K. 2002. Energy dissipation and photoinhibition in Douglas-fir needles with a fungal-mediated reduction in photosynthetic rates. J. Phytopathol. Phytopathol. Z. 150:674-679.

31. Manter, D. K., Bond, B. J., Kavanagh, K. L., Rosso, P. H., and Filip, G. M. 2000. Pseudothecia of Swiss needle cast fungus, Phaeocryptopus gaeumannii, physically block stomata of Douglas fir, reducing $\mathrm{CO}_{2}$ assimilation. New Phytol. 148:481-491.

32. Manter, D. K., Bond, B. J., Kavanagh, K. L., Stone, J. K., and Filip, G. M. 2003. Modelling the impacts of the foliar pathogen, Phaeocryptopus gaeumannii, on Douglas-fir physiology: net canopy carbon assimilation, needle abscission and growth. Ecol. Model. 164:211-226.

33. Manter, D. K., Reeser, P. W., and Stone, J. K. 2005. A climate-based model for predicting geographic variation in Swiss needle cast severity in the Oregon coast range. Phytopathology 95:1256-1265.

34. Marks, G. C., and Pederick, L. A. 1976. Sensitivity of Douglas-fir provenances to Swiss needle cast disease. Phaeocryptopus gaeumannii on Pseudotsuga menziesii. In: Research Activity. Forests Commission, Melbourne, Australia.

35. McCormick, F. A. 1939. Phaeocryptopus gaeumannii on Douglas fir in Connecticut. Plant Dis. Rep. 23:368-369.

36. McKimm, R. J. 1975. The distribution and effects on tree growth of Phaeocryptopus gaeumannii. In: Research Activity for 1974. R. Idczak, ed. Forests Commission, Melbourne, Australia.

37. Merkle, R. 1951. Über die Douglasien-Vorkommen und die Ausbreitung der Adelopus-Nadelschütte in Württemberg-Hohenzollern. Allg. Forst Jagdzt. 122:161-191.

38. Merrill, W., and Longnecker, J. 1973. Swiss needlecast of Douglas-fir in
Pennsylvania. Plant Dis. Rep. 57:984.

39. Michaels, E., and Chastagner, G. A. 1984. Distribution, severity, and impact of Swiss needle cast in Douglas-fir Christmas trees in western Washington and Oregon. Plant Dis. 68:939-942.

40. Ministry of Agriculture and Forestry. 2009. National Exotic Forest Description as at 1 April 2009. Ministry of Agriculture and Forestry, Wellington, New Zealand.

41. Nüsslein, H. 1970. Growing Douglas fir in the Spessart [in German]. Mitt. St. Forstverw. Bayerns 38:5-126.

42. Osorio, M. 2007. Detección del hongo defoliador Phaeocryptopus gaeumannii en plantaciones de Pseudotsuga menziesii de Valdivia, Chile [Detection of the needle cast fungus Phaeocryptopus gaeumannii in plantations of Pseudotsuga menziesii in Valdivia, Chile]. Bosque 28:6974

43. Peace, T. R. 1962. Pathology of Trees and Shrubs, with Special Reference to Britain. Clarendon Press, Oxford.

44. Pillar, C. H., and J. D. Dunlop. 1990. The permanent sample plot system of the New Zealand Ministry of Forestry. Paper read at Forest Growth Data: Retrieval and Dissemination. Proc. Joint IUFRO Workshop S4.02.03 and S4.02.04. Gembloux, Belgium.

45. Rannert, H. 1972. Performance of Douglas fir on cretaceous flysch [in German]. Allg. Forstztg. 83:249-250.

46. Rohde, T. 1938. Bedeutung der Schweiser Douglasienschütte für den Douglasien anbau. Z. Pflanzenkrankh. (Pflanzenpathol.) Pflanzenschutz 48:424-425.

47. Rohde, T. 1938. Können wir den weiteren Anbau der Douglasie noch verantworten? Dtsch. Forstwirt. 20:81-85.

48. Rohde, T. 1938. Ueber den Krankheitsverlauf bei der Schweizer Douglasienschütte. Z. Pflanzenkrankh. 48:49-57.

49. Rosso, P. H., and Hansen, E. M. 2003. Predicting Swiss needle cast disease distribution and severity in young Douglas-fir plantations in coastal Oregon. Phytopathology 7:790-798.

50. Stefanelli, A. 1963. Dell'infezione del "Phaeocryptopus gaeumannii" sulla douglasia in provincial di Udine [The Phaeocryptopus gaeumannii infection in Douglas fir in the province of Udine]. Monto Boschi 14:405413.

51. Stone, J. K., Capitano, B. R., and Kerrigan, J. L. 2008. The histopathology of Phaeocryptopus gaeumannii on Douglas-fir needles. Mycologia 100:431-444.

52. Stone, J. K., Coop, L. B., and Manter, D. K. 2008. Predicting effects of climate change on Swiss needle cast disease severity in Pacific Northwest forests. Can. J. Plant Pathol. 30:169-176.

53. Stone, J. K., Hood, I. A., Watt, M. S., and Kerrigan, J. L. 2007. Distribution of Swiss needle cast in New Zealand in relation to winter temperature. Australas. Plant Pathol. 36:445-454.

54. Stoodley, M. A., and Hood. I. A. 1984. Distribution of Phaeocryptopus gaeumanii on Douglas fir in a New Zealand forest. Australas. Plant Pathol. 13:2-3.

55. Strittmatter, W. 1974. Ökologische und biologische studien an der Baumart Douglasie im Zusammenhang mit dem Auftreten von Phaeocryptopus gäumannii (Rohde) Petr. In: Schriftenreihe der Landesforstverwaltung Baden-Württemberg. Ministerium für Ernährung, Landeswirtschaft und Umwelt, Stuttgart, Germany.

56. Syrach-Larsen, C. 1940. Planting of Douglas [in Danish]. Dan. Skovforen. Tidsskr. 25:579-582.

57. Temel, F., Johnson, G. R., and Stone, J. K. 2004. The relationship between Swiss needle cast symptom severity and level of Phaeocryptopus gaeumannii colonization in coastal Douglas-fir (Pseudotsuga menziesii var. menziesii). For. Pathol. 34:383-394.

58. Thulin, I. 1949. Beskadigelser af Douglasgran (Pseudotsuga taxifolia) I Danmark I Vinteren 1946-47 [Damage to Douglas fir in Denmark in the Winter of 1946-47]. Forstl. Forsoegsvaes. Dan. 19:20-329.

59. Wilcox, M. D. 1978. Genetic resources and supply of Douglas fir seed in New Zealand. Pages 210-217 in: A Review of Douglas fir in New Zealand. R. N. James and E. H. Bunn, eds. FRI Symp. No. 15. New Zealand Forest Research Institute, Rotorua, New Zealand.

60. Winton, L. M., Manter, D. K., Stone, J. K., and Hansen, E. A. 2003. Comparison of biochemical, molecular, and visual methods to quantify Phaeocryptopus gaeumannii in Douglas-fir foliage. Phytopathology 93:121-126.

61. Witte, A. 1948. Skadegörelse på Douglas-Gran [Damage done to Douglas fir]. Sven. Skogsvaardsfoeren. Tidskr. 46:140-148.

62. Zimmerle, H. 1952. Ertragszahlen für grüne Douglasie, japaner Lärche und Roteiche in Würtemberg. Mitt. Württemb. Forst. Vers Anst. 9:44.

63. Zycha, H. 1948. Ist die Douglasie gefährdet? [Is Douglas fir threatened?]. Forst Holzwirt 3:231-232. 